\title{
Study of Food Security Based on Expenditure Household Farmers Tea on the Community Plantation at Citengah Village, Sumedang Selatan District
}

\author{
Yuliana Samantha S.P., M.EP ${ }^{1 *}$, Ning Sri Menganti S.Pd., MP², Lilis Rosdiana Amaliah S.Pd., M.Pd ${ }^{3}$ \\ ${ }^{1}$ Departement of Agriculture Winaya Mukti University, Indonesian \\ ${ }^{2}$ Departement of Agriculture Winaya Mukti University, Indonesian \\ ${ }^{3}$ Departement of Agriculture Winaya Mukti University, Indonesian \\ *yuliana.faperta@gmail.com,ning.srimenganti@gmail.com, lilisamaliah87@gmail.com
}

\begin{abstract}
Food insecurity and famine often happened to small-scale farmers, fisherman and woodsmen. In this regard farmers in plantation community sector could not adapt to use subsistence living to fulfill their basic needs unlike food crops farmers. Research used quantitative design with descriptive survey. Sample of the research was families working as tea sharecroppers amounted to 51 families. Respondents were chosen through stratified random sampling based on extent of their arable land. Data gathered was frequency of cross tabulation result with to measure the food security level of the household consumption subsystem, the indicator classification is used, namely food expenditure share. that food expenditure share $>\mathbf{6 0}$ percent of total household expenditure, If the expense share is $\leq$ $60 \%$ then categorized as food vulnerable. Characteristics of tea sharecopper Families are average age of the head of family was 52 years old, average education was in the level of elementary school, average income family was IDR 4.852 .859 for a month and average monthly per capita income was IDR 1.333.942. There were $64,71 \%$ was categorized as food secured, $35,29 \%$ was categorized insecure based on expenditure. Comparison from strata, if strata of tea sharecopper families at good level, so food security was also good.
\end{abstract}

Keywords: Tea Farmer, Food Security, Farmer Family, Field, Stratified

\section{INTRODUCTION}

The challenges of Indonesia's agricultural development include how to meet food needs and family nutrition balance. Some experts agree that food security contains at least three main elements, namely "availability, distribution and consumption of food", where the elements of distribution and consumption constitute a description of people's accessibility to food ". One of these elements is not fulfilled, so a country cannot be said to have good food security. Even though food is sufficient at national and regional levels, if individual access to meet their food needs is not evenly distributed, then food security is still said to be fragile. Access to food, food availability and risk to food access and availability are essential determinants of food security.

Until now the tea commodity is still one of the biggest contributors to the trade in the agricultural sector in Indonesia.
Based on 2015 data, the national tea plantation area is around 122,206 ha with the largest development center in West Java covering 95,496 ha or $77.6 \%$. Smallholder plantations covering an area of 56,258 ha. Large state plantations covering 38,103 ha, private plantations covering 27,845 ha. The number of farmers involved in tea plantations is 20,000 households, 70 percent of whom are in West Java. Tea development centers in Indonesia are located in West Java with an area of 95,496 ha or $77.62 \%$ of the national tea area. Its location is spread in Bandung Regency, West Bandung,

Garut Tasikmalaya, Cianjur, Sukabumi, Bogor, Subang, Purwakarta, Sumedang, Ciamis and Majalengka.

In smallholder plantations, the area cultivated is small but in large numbers. Cultivators (penyakap) are farmers who control their business because of rent or because the profit sharing is in accordance with the agreed agreement. Citengah Village in South Sumedang is known as a place for smallholder tea plantation agrotourism. Most of the people make a living as tea cultivators on the people's tea plantations. In connection with the explanation above, the research on the Study of Farmers' Household Food Security in Tea Cultivators at the People's Plantation in Citengah Village, South Sumedang District, Sumedang District aims to find out the condition of household food security of tea cultivators.

Food is anything derived from biological and water sources, whether processed or not and intended for food or drink for human consumption, including food additives, stuffs, and other materials that used in the process of preparation, processing, and / Or food or beverage making (PP RI No.68/2002 on Food Security).

The agricultural development success in agricultural sector in a country should be reflected by the state's ability in food self-sufficiency or at least food security. In Indonesia, food security is a very important topic which is not only seen from social and economic value, but also this problem has a huge political consequences. Food security has become increasingly important since Indonesia is not one of the members of the World Trade Organization (WTO) anymore. Therefore, the government must pay attention to the food 
production continuity in the country to ensure the food security. On the other hand, Indonesia cannot hamper imports of food from outside the country. In other words, if Indonesia is not ready in the WTO it can make Indonesia very dependent on food imports and threaten food security within the country. (Tulus Tambunan, 2010).

According to Endro Pranoto (2008) food security is a household (including individuals in it), not just the aspect of the number that needs to be considered, but also other aspects such as food quality, continuity of availability and affordability. It can be seen from the perspective of quality, continuity and affordability (this price aspect) that means the conception of food security contains the content of justice. Good food should be available sustainably to all levels of society.

The concept of national food security stipulated in Law No. 17 that emphasizes the access of every household to adequate, quality food, and affordable prices, even though household words do not necessarily guarantee that every individual in the household has a relationship power (Pambudy in Tambunan 2010). The implication of the policy of this concept is that the government, on the one hand, is obliged to ensure food sufficiency in terms of quantity with good quality and price stability, and on the other hand, the increase in public income, in particular from the low income group.

Irham (2008) in Tambunan (2010) argues that in addition to Law No. 7/1996 does not comply with the Ekosob Covenant, and also has not touched on these four aspects yet. For example, Law No. 7/1996 "obliterates" the obligation and responsibility of the state in the fulfillment of the right to food, by giving part of the obligation load to the public (Article 45). In addition, he said that the "government" in this Act should be further affirmed, whether it is the local government (Pemda) or not. It became very crucial after the occurrence of regional autonomy. Irham even argues that in the context of otda, it has a central role in fulfilling the food availability of the local government.

Definition of food security often referred to in Indonesia: (1). Food Law No.7 Year 1996: the condition of food needs for households reflected in the availability of food adequacy, both in quantity and quality, safe, equitable and affordable; (2). Government Regulation No. 68 of 2002 states that food security is the condition of food for the household that is reflected in the availability of adequate food, both quantity and quality, safe, equitable and affordable. (3). FAO (1997): the situation in which all households have physical and economic access to food for all their family members, where households are not in risk of losing both accesses.

Based on these definitions, it can be concluded that food security has five elements to fulfill: (1) Oriented household and individual; (2) The time dimension whenever food is available and accessible; (3) Emphasize access to household and individual food, physical, economic and social; (4)
Nutrition fulfillment oriented; (5) Intended to a healthy and productive life.

Although food is available in the market but if the price is high (and household purchasing capability is low) it will result that they are unable to access foodstuffs in the market. This condition could trigger agricultural people in Tegalmaja Village to turn farming into non-core livelihoods for them, and cause behavior change as positive and negative impact as well on the change. If farmers have job other than agriculture, the level of dependence on the land is low.

Then, the question comes up, how socioeconomic conditions that occur when farmers sell some of their lands yet still do the main job as farmers, are associated with progressively narrow land, clean water sanitation and family consumption patterns in food security measurement, get information that industrial land In Tegalmaja Village. Therefore, it is interesting to investigate further on how real food resilience of the farmer's households with environmental conditions and phenomena because of food is a primary need to be fulfilled.

The identification of the problem is the characteristics of farmers who have taken over land functions in Tegalmaja Village and the level of household food security in Tegalmaja Village after the land conversion. This research attempts to know that food security being emphasized from the household consumption side. Because according to the theory of food availability that is macroly enough to guarantee the adequacy of food at household and individual levels, and two very important elements in supporting household food security are smooth distribution and community purchasing power. The measurement of food security can be started from the household level. Because if every Indonesian household has reached the stages of food security, it will be automatically achieved by the people, regional, and national food security.

\section{RESEARCH METHODS}

The location of the research is purposive, considering that Tegalmaja Village has large industrial area potential based on the location of the second land conversion in Kragilan District, Serang Regency.

This study uses a qualitative method. The research of qualitative method is a method based on data from measurement result, based on existing research variable. The technique of research in obtaining data is using interview technique, interview and observation, observation with sample selection using Stratified Random Sampling. The study included questionnaire that filled by respondents, and direct interviews to informants to get more information, to conduct literature studies and process data. The characteristic difference may exist on any element or element of the population that is not important to the analysis plan. (Mustafa, 2001). 
Before measuring the level of food security, known as farmers' household income, both from the agricultural sector and other sectors which presented in the form of tables and food expenditure share. Here are the calculations:

\section{Farmers' Household Income}

Farmer's income is the total income of farmers from farms and non- farms, including from family members that earned within a certain period of time.

$$
\begin{aligned}
& \text { TFFI = IF+ OF+ IFFI } \\
& \text { IF }=\text { Farmer's income from farming } \\
& \text { OF }=\text { Outside farm income generated by farmers } \\
& \text { IFFI }=\text { Income from farmer family members } \\
& \text { TFFI }=\text { Total farmer family income }
\end{aligned}
$$

\section{Farmer's Household Expenditure}

To calculate farmer's purchasing power, by calculating the total expenditure of farmers based on their consumption pattern. Farmers' expenditure that seen from their consumption pattern is expenditure for the fulfillment of the main needs of farmers and families. Especially food expenditure based on UNDP / World Bank standards (2005) which is adjusted to the condition of the Indonesian community, particularly farmers, consisting of 20 items per unit of Rp/month.

\section{Food Production Share}

\section{Food expenditure \\ Total household expenditure $\quad \times 100 \%$}

To measure the food security level of the household consumption subsystem, the indicator classification is used, namely food expenditure share (Jonsson and Toole, in Purwantini 1999 et al.) that food expenditure share> 60 percent of total household expenditure, If the expense share is $\leq 60 \%$ then categorized as food vulnerable.

\section{Consumption Subsystem}

\section{Definition of Consumption Subsystem}

The Consumer Subsystem directs the national food utilization pattern to meetquality, diversity, nutrition, safety and halal efficiencies as well as efficiency to prevent wastage. Consumption quality is also directed to maximize food utilization in the body through increased awareness of the importance of diverse consumption patterns with balanced nutrition including energy, protein, vitamins and minerals. Balanced nutrition efforts are also associated with sanitation and hygiene maintenance efforts and infectious diseases prevention in the household environment. In order to achieve these goals, community education and awareness are needed
(Food Consumption and Safety Center, 2007). Riely et.al in Hanani (2010) consumption subsystem is a food intake (food utilization) that is the use of food for the healthy living needs that includes energy and nutrition needs, water and environmental health. The effectiveness of food absorption is dependent on household/individual knowledge, sanitation and water availability, health facilities and services.

James F Engel (1994), Law says that the poorer condition of a person, the higher the proportion of consumption expenditure for food. Engel's law also states that the proportion of household budgets allocated for food purchases will be smaller as income levels increase.

The consumption pattern of farmers households is one of the indicators infarmersability to create savings or capital for the next farming. This expenditure pattern will illustrate how a farmer's household allocates his household income to meet the needs of consumption and other needs. Masters and Munir (2008) in his research that the general share of farm households production is dominated by the production of non-food, which was valued at more than $50 \%$ of the total production. Yet, it still needs to be examined, whether these conditions apply to all categories of farmers or bias in terms of land tenure, the number of family members, and others. The consumption pattern of farmers viewed the production to meet the needs of rural farmers and their families, especially spending on food by standard UNDP/World Bank (2005) adapted to the conditions of the Indonesian people, especially small holders which consists of 20 items (rice, eggs, fish, fish salt, beef, chicken, tofu, tempeh, milk, vegetables, nuts, fruits, salt, sugar, flour, tea, coffee, cigarettes, instant noodles, and fuel), while other expenses are school fees, transportation, medicines, savings, and others in units of IDR/month.

\section{Respondent Farmer Characteristics}

Land tenure as a basis for the stratification of farm households.

Table 1. Characteristics of Farmers Cultivating Tea Land Based on Land Size

\begin{tabular}{|l|l|c|c|}
\hline Category & $\begin{array}{l}\text { Land } \\
\text { Area } \\
\text { (ha) }\end{array}$ & Total & $\%$ \\
\hline Narrow & $<0,5$ & 24 & 47,05 \\
\hline Middle & $0,5-1$ & 20 & 39,22 \\
\hline Wide & $>1$ & 7 & 47,05 \\
\hline \multicolumn{2}{|c|}{ Total } & 36 & 100 \\
\hline
\end{tabular}

The magnitude of the percentage value of land acquisition is related to the farmers' capital in carrying out this tea farming. Where those who have strong capital, he is the one who can master the land that is larger than the others. Even though the land tenure status is only as a land of land (land not 
owned) that does not need to pay for the land, but for variable costs (non-fixed costs) such as fertilizers, pests and diseases, farming equipment, and labor costs borne by sharecroppers that. Of course, the more extensive cultivated land they have, the higher the production costs they have to spend. This is where the weakness of the farmers is weak capital in the management of land which then affects the production yield, income, then the income they receive.

\section{Demographic Characteristics of Farmer Households}

The demographic characteristics of households in this study are in the form of demographic characteristics that include age, formal education, non- formal education, and family dependents. Information about household characteristics is very important to provide an overview of the actual condition of the household before explaining the level of household food security.

Table 2. Characteristics Demographic of Farmer Households Cultivating Tea Land According to Land Strata (Average)

\begin{tabular}{|c|c|c|c|c|}
\hline Characteristics & $\begin{array}{l}\text { Narrow } \\
\text { Land }\end{array}$ & $\begin{array}{l}\text { Middle } \\
\text { Land }\end{array}$ & $\begin{array}{l}\text { Wide } \\
\text { Land }\end{array}$ & Total \\
\hline $\begin{array}{l}\text { Age of } \\
\text { Householder (yr) }\end{array}$ & 55 & 48,36 & 54,33 & 52,31 \\
\hline $\begin{array}{l}\text { Formal Education } \\
\text { of Housholder } \\
\text { (yr) }\end{array}$ & 7,4 & 7,5 & 6,8 & 21,7 \\
\hline $\begin{array}{l}\text { Nonformal } \\
\text { Education of } \\
\text { Housholder (yr) }\end{array}$ & 9 & 10 & 5 & 24 \\
\hline $\begin{array}{l}\text { Formal Education } \\
\text { of man in } \\
\text { Houshold (yr) }\end{array}$ & 7,3 & 7,6 & 7 & 21,9 \\
\hline $\begin{array}{l}\text { Formal Education } \\
\text { of woman in } \\
\text { Houshold }(\mathrm{yr})\end{array}$ & 7,1 & 8,25 & 9 & 8,1 \\
\hline $\begin{array}{l}\text { Total of } \\
\text { Household burden } \\
\text { (people) }\end{array}$ & 27 & 35 & 13 & 75 \\
\hline $\begin{array}{l}\text { Total of man } \\
\text { Houshold } \\
\text { unproductive } \\
\text { (people) }\end{array}$ & 2 & 6 & 4 & 12 \\
\hline $\begin{array}{l}\text { Total of woman } \\
\text { Houshold } \\
\text { unproductive } \\
\text { (people) }\end{array}$ & 6 & 8 & 2 & 16 \\
\hline $\begin{array}{l}\text { Total of man } \\
\text { Houshold } \\
\text { productive } \\
\text { (people) }\end{array}$ & 13 & 14 & 5 & 32 \\
\hline $\begin{array}{l}\text { Total of woman } \\
\text { Houshold } \\
\text { productive } \\
\text { (people) }\end{array}$ & 6 & 7 & 2 & 15 \\
\hline
\end{tabular}

Non-formal education, it appears that there is a positive relationship with the strata of land area, there is a tendency, the wider the cultivated land the more number of farmers who have attended non-formal education. The formal education in question is this research is the Integrated Pest Management Field School (SLPHT) program organized by the Plantation Office in collaboration with the Agriculture Office of West Java Province in 2003. This trend roughly indicates that better learning experience will have an effect on mastery the land is due to the farmers' mindset that is quite good based on the knowledge he got so that he can properly manage his farm so that the farmers are able to expand their land with the knowledge they get. The opposite indication that because farmers have a broad understanding, they are required to have sufficient knowledge to supply their farming management so as not to experience a decrease in productivity and the quality of their tea production.

\section{Farmer's Household Income}

The role of tea appears to be greater in medium and large land farmers. This shows that tea commodities in tea farmer households are still an important commodity. In medium land and brush land households, the contribution of farm income is increasing. This phenomenon shows that judging from the size of household income, farm income plays an important role in all household strata. To find out the contribution of income of household heads and household members to household income can be seen in the following table 3.

\begin{tabular}{|c|c|c|c|c|c|c|c|c|}
\hline \multicolumn{9}{|c|}{$\begin{array}{l}\text { Table } 3 \text { Income Contribution of Eac } \\
\text { Household Income (Average) }\end{array}$} \\
\hline \multirow{2}{*}{ Income } & \multicolumn{2}{|c|}{ Narrow Land } & \multicolumn{2}{|c|}{ Middle Land } & \multicolumn{2}{|l|}{ Wide Land } & \multicolumn{2}{|l|}{ Total } \\
\hline & $\mathrm{Rp}$ & $\%$ & $\mathrm{Rp}$ & $\%$ & $\mathrm{Rp}$ & $\%$ & $\mathrm{Rp}$ & $\%$ \\
\hline Householder & T22.152 & 25 & 1.281 .475 & 35 & $2.101 .285,7$ & 42,84 & \begin{tabular}{|l} 
\\
\end{tabular} & 36,28 \\
\hline $\begin{array}{l}\text { Household of } \\
\text { member }\end{array}$ & 434.275 & 18 & 335.000 & 9 & $78.571,43$ & 1,60 & 847.846 & 7,68 \\
\hline $\begin{array}{l}\text { Householder } \\
+ \text { Household } \\
\text { of } \\
\text { member }\end{array}$ & 1.056 .527 & 43 & 1.616 .475 & 44 & 2.179.857,1 & 44,45 & 4.852 .859 & 43,96 \\
\hline $\begin{array}{l}\text { Income } \\
\text { /Cap/month }\end{array}$ & 353.227 & 14 & 435.882 & 12 & $544.833,3$ & 11,11 & 1.333 .942 & 12,08 \\
\hline
\end{tabular}

Based on the land area strata, it was found that the greater the land area, the higher the contribution and average income of the head of the family. But on the contrary, the contribution and average income to household members are even smaller in the broader land strata. If referring to Sumedang Regency's Regional Minimum Wage (RRMW) of IDR. $1,058,978.00$, the income per capitan of the tea farmer's household is still low.

\section{Household expenditure}

Household expenditure is the use of various food and nonfood items for daily use. The need for these items is fulfilled by buying from markets/stalls or those produced by households through production activities on their own farms. In general, this type of expenditure can be grouped into food and non-food expenditure. 
The share of household food expenditure is an indicator of household food security (Pakpahan et al., 1993; Soehardjo, 1996). In detail, the land expenditure according to land tenure is presented in Table 4 presented the structure of household expenditure for one month according to the strata of land area. The absolute size of each type of household expenditure seems to be directly proportional to the area of land. The higher the household strata according to land area, the greater household expenditure.

Compare between food expenditure and non-food expenditure, it will be seen that the higher the household level, the non-food expenditure is greater than the food expenditure. This turns out to be in line with economic law showing that the higher the level of population income the higher the percentage or portion of expenditure spent on non-food items (the lower the percentage for food). Engel's law says that the proportion of household budget allocated to buying food will be smaller when income levels increase.

Table 2. Characteristics Demographic of Farmer Households Cultivating Tea Land According to Land Strata (Average)

\begin{tabular}{|l|c|c|c|c|}
\hline $\begin{array}{l}\text { Spending } \\
\text { patterns }\end{array}$ & $\begin{array}{c}\text { Narrow } \\
\text { Land }\end{array}$ & Middle Land & Wide Land & Total \\
\hline $\begin{array}{l}\text { Food } \\
\text { (IDR) }\end{array}$ & 456.750 & 554.600 & $702.285,71$ & 1.713 .636 \\
\hline $\begin{array}{l}\text { Non Food } \\
\text { (IDR) }\end{array}$ & $419.135,42$ & 811.700 & $1.206 .857,1$ & 2.437 .693 \\
\hline $\begin{array}{l}\text { Total } \\
\text { Spending } \\
\text { (IDR) }\end{array}$ & $875.885,42$ & 1.366 .300 & $1.909 .142,86$ & 4.151 .328 \\
\hline $\begin{array}{l}\text { Share of } \\
\text { Food } \\
\text { Expenditure } \\
\mathrm{s}(\%)\end{array}$ & 52,15 & 40,59 & 36,79 & 41,28 \\
\hline
\end{tabular}

It has been estimated that the share of food expenditure in the narrow land household strata is the highest. When viewed from the source of the acquisition, most of the food expenditure was purchased from the nearest food stalls and markets, the rest was provided by themselves from various sources, including from own farms for those who have paddy fields. The high portion of food expenditure originating from the market indicates high household demand for cash. This proportion applies to all strata. This means that the difference in farming land area does not affect the proportion of food needs of the market or the role of the farm itself as a food provider is not affected by the land area.

The share of household food expenditure can be one indicator of household food security (Pakpahan et al., 1993; Soehardjo, 1996). Total household expenditure can also be seen as a household approach. Therefore understanding the pattern of expenditure (food and non-food) can be used as an indicator of household food security. In accordance with the category of categorizing household strata, narrow household strata economically (proxied from the pattern of food expenditure) including less prosperous, in this case food expenditure $>60 \%$. Whereas small land households and large areas of food expenditure $<60 \%$ belong to the prosperous class. Therefore, Food Security based on household expenditure can be seen in the following table 5 .

Table 5. Food Security Based on Expenditure

\begin{tabular}{|c|c|c|c|c|}
\hline \multirow[b]{2}{*}{ Characteristic } & \multicolumn{4}{|c|}{ Food Security } \\
\hline & $\begin{array}{c}\text { Secure } \\
<60 \%\end{array}$ & $\%$ & $\begin{array}{c}\text { Insecure } \\
>60 \%\end{array}$ & $\%$ \\
\hline $\begin{array}{l}\text { Narrow } \\
\text { Land }\end{array}$ & 12 & $\begin{array}{l}36, \\
36\end{array}$ & 12 & $\begin{array}{c}66,6 \\
7 \\
\end{array}$ \\
\hline $\begin{array}{l}\text { Middle } \\
\text { Land }\end{array}$ & 15 & $\begin{array}{l}45 \\
45\end{array}$ & 5 & $\begin{array}{c}27,7 \\
8\end{array}$ \\
\hline $\begin{array}{l}\text { Wide } \\
\text { Land }\end{array}$ & 6 & $\begin{array}{l}18 \\
18\end{array}$ & 1 & 5,56 \\
\hline Total & 33 & 100 & 18 & 100 \\
\hline
\end{tabular}

Based on the results of the study we have 33 of 51 about $64,71 \%$ can be classified as secured and another 18 of 51 about $35,29 \%$ can be classified as unsecured. It can be seen that the majority of food resistant is in the medium area and the narrow land is almost half of the sample stated as not food resistant. This is related to household income both householder income and combined income plus household member income. Income of household also impact on expenditure habit.

Based on farmer household research in expenditure habit, they spent on affordable food products, such as fish, tempeh, tofu and also other varieties vegetables as a complement to rice. They rarely spent on breast chicken and never bought beef.

\section{CONCLUSION}

1. Characteristics of socioeconomic farming households that have been shifting agricultural land are as follows:

(A) The average characteristic of householder in all strata is 52 years of age is productive. The average level of family head education is at the elementary level (SD) that classified as primary education.

2. The proportion of farmer households who have secured food was 33 of 51 about $64,71 \%$ was classified as secured and another 18 of 51 about $35,29 \%$ can be classified as insecure based on expenditure. 


\section{REFERENCES}

Badan Pusat Statistik. 2018. Pola Konsumsi Berdasarkan Rata- rata Pendapatann Per Kapita 2017-20178. BPS

Dirgahayu, Dede. Analisis Spasial Konversi Lahan di Kabupaten Bekasi (Studi Kasus di Kecamatan Cibitung dan Tambun. 2000. Jurnal Penginderaan Jauh dan Pengolahan Dala Citra Digital Vol. 1, No. 1

Djodjodipuro, Marsudi. Teori Lokasi. 1992. Jakarta. Lembaga Penerbit Fakultas Ekonomi Universitas Indonesia.

Engel, James F., Roger D. Blackwell, dan Paul Winiard. Perilaku Konsumen. 1994. Jakarta. Edisi II Binarupa Aksara

FAO. 1996. World Food Summit, 13-17 November 1996. Rome, Italy: Food and Agriculture Organisation of the United Nations.

Gasperz, Vincent. 1990. Teknik Penarikan Contoh Untuk Penelitian Survei. Tarsito. Bandung

Hanani, Nuhfil. 2010. Pengertian Ketahanan Pangan. Fakultas Pertanian Universitas Brawijaya. Malang.

Hariyanto. Pola dan Intensitas Konversi Lahan Pertanian di Kota Semarang Tahun 2000-2009. 2009. Jurnal Vol 7, No. 1

Karyani, Tuti.,Endah Djuwendah, dan

Hepi Hapsari. 2002. Ketahanan Pangan Di Tingkat Rumah Tangga Di Daerah Jawa Barat. Fakultas Pertanian Unpad.

Pakpahan, Agus, Memed Gunawan, Achmad Djauhari, Sahat M. Pasaribu, Aladin Nasution, dan Supena Friyanto. 1992. Cassava Marketing in Indonesia.

Monograph Series No.2. Bogor: Center for AgroSocioeconomic Research. Agency for Agricultural Research and Development.

Pasadaran, Effendi. 2006.Alternatif Kebijakan Pengendalian Konversi Lahan Sawah Beririgasi di Indonesia dalam Jurnal Litbang Pertanian 25 (4) 2006.

Pasadaran, Effendi. 2006.Alternatif Kebijakan Pengendalian Konversi Lahan Sawah Beririgasi di Indonesia dalam Jurnal Litbang Pertanian 25 (4) 2006.

PPK-LIPI. 2004. Ketahanan Pangan, Kemiskinan dan Demografi Rumah Tangga. Seri Penelitian PPK-LIPI No. 56/2004. Jakarta: Puslit kependudukan _ LIPI.

PPK-LIPI. 2004. Ketahanan Pangan, Kemiskinan dan Demografi Rumah Tangga. Seri Penelitian PPK-LIPI No. 56/2004. Jakarta:

Puslit kependudukan _ LIPI. Purwantini, T. Bastuti, Handewi P.S

Rachman dan Yuni Marisa. 1999. Analisis Ketahanan Pangan Regional dan Tingkat Rumah Tangga. Pusat Analisis Sosial Ekonomi dan Kebijakan Pertanian. Bogor.

Raharto, Aswatini., and Haning Romdiati. 2000. Identifikasi Rumah Tangga Miskin, dalam Seta, Ananto Kusuma et.al (editor), Widyakarya Nasional Pangan dan Gizi VII, hal: 259-284. Jakarta: Lembaga Ilmu Pengetahuan Indonesia (LIPI).

Raharto, Aswatini., and Haning Romdiati. 2000. Identifikasi Rumah Tangga Miskin, dalam Seta, Ananto Kusuma et.al (editor), Widyakarya Nasional Pangan dan Gizi VII, hal: 259-

284. Jakarta: Lembaga Ilmu Pengetahuan Indonesia (LIPI).

Republik Indonesia. 2002. Peraturan Pemerintah Republik Indonesia Nomor 68 Tahun 2000 Tentang Ketahanan Pangan. Jakarta: Sekretaris Negara RI.

Ruswandi, Agus et. Al. 2007. Dampak Konversi Lahan Pertanian Terhadap Kesejahteraan Petani dan Perkembangan Wilayah :Studi Kasus di Daerah Bandung Utara. Journal Agro Economic Vol. 25 No 022007.

Soehardjo. 1996. Pengertian dan Kerangka Pikir Ketahanan Pangan Rumah Tangga. Makalah disampaikan pada Lokakarya Ketahanan Pangan Rumah Tangga oleh Departemen Pertanian 26-30 Mei 1996.

Soemarno. 2010. Strategi Pemenuhan Kebutuhan Pangan Rumah Tangga Petani. Fakultas Pertanian. Universitas Brawijaya.

Soemarwoto, Otto. Analisis Dampak Lingkungan. 1988. Yogyakarta. Gajah Mada University Press.

Suhardjo. 1985. Pangan, Gizi dan Pertanian. Penerbit UI (UI press). Jakarta.

Suparmoko. 2002, Penilaian Ekonomi: SumberdayaAlam dan Lingkungan, Yogyakarta: BPPE.

Tambunan, Tulus. 2010. Pembangunan Pertanian dan Ketahanan Pangan. Jakarta: Universitas Indonesia.

Utomo, M., Eddy Rifai dan Abdulmultalib Thahir. 1992. Pembangunan dan Alih Fungsi lahan. Lampung. Universitas Lampung

Wiradi, Gunawan. 2000. Reforma Agraria; Perjalanan Yang Belum Berakhir. Yogyakarta: Pustaka Belajar Offset. 